\title{
Antitumor effect of isoquercetin on tissue vasohibin expression and colon cancer vasculature
}

\author{
Daniel de Castilho da Silva ${ }^{1, *}$, Guilherme Di Camillo Orfali2,*, Maycon Giovani \\ Santana ${ }^{3}$, Jessica Kaoru Yamamoto Palma ${ }^{3}$, Isabella Ramos de Oliveira Assunção ${ }^{3}$, \\ Isadora Moraes Marchesi' ${ }^{2}$, Ana Yoshie Kitagawa Grizotto ${ }^{2}$, Natália Peres Martinez ${ }^{1}$, \\ Simone Felliti ${ }^{4}$, José Aires Pereira ${ }^{5}$ and Denise Gonçalves Priolli ${ }^{6}$ \\ ${ }^{1}$ Programme Stricto Sensu in Health Science, Sao Francisco University Medical School, Sao Paulo, Brazil \\ ${ }^{2}$ Escola Paulista de Medicina, São Paulo, Brazil \\ ${ }^{3}$ Scientific Initiation Programme, Sao Francisco University Medical School, Sao Paulo, Brazil \\ ${ }^{4}$ Department of Oncology, Sao Francisco University Medical School, Sao Paulo, Brazil \\ ${ }^{5}$ Department of Pathology, Sao Francisco University Medical School, Sao Paulo, Brazil \\ ${ }^{6}$ Postgraduate Programme Stricto Sensu in Health Science, Sao Francisco University Medical School, Sao Paulo, Brazil \\ *These authors contributed equally to this work \\ Correspondence to: Denise Gonçalves Priolli, email: depriolli@gmail.com \\ Keywords: target; angiogenic proteins; neoplasms; flavonols; antitumor assays-xenograft model \\ Received: September 24, $2021 \quad$ Accepted: December 08, $2021 \quad$ Published: February 08,2022 \\ Copyright: () 2022 da Silva et al. This is an open access article distributed under the terms of the Creative Commons Attribution License \\ (CC BY 3.0), which permits unrestricted use, distribution, and reproduction in any medium, provided the original author and source are \\ credited.
}

\section{ABSTRACT}

Tumor cells trigger angiogenesis through the expression of angiogenic factors. Vasohibins (VASHs) are a family of peptides that regulate angiogenesis. Flavonoids have antiproliferative antitumor properties; however, few studies have highlighted their antiangiogenic potential. This study evaluated the flavonoid isoquercetin (Q3G) as an antitumor compound related to colon cancer vascularization and regulation of VASH1 and 2. Mice bearing xenogeneic colon cancer $(n=15)$ were divided into 3 groups: Q3G-treated (gavage, daily over a week), bevacizumabtreated (intraperitoneal, single dose), or untreated animals. Tumor growth, histological characteristics, blood vessel volume, and VASH1 and 2 expressions were analyzed. Q3G impaired tumor growth and vascularization, upregulated VASH1, and downregulated VASH2 in comparison to untreated animals. Mice treated with Q3G showed approximately $65 \%$ fewer blood vessels than untreated animals and $50 \%$ fewer blood vessels than mice treated with bevacizumab. Thus, we show that Q3G has antitumor activity, impairs vascularization, and differentially modulates VASH1 and 2 expressions in colon cancer.

\section{INTRODUCTION}

Angiogenesis is characterized by the establishment of new blood vessels (BV) through stimulation of endothelial proliferation. The steps involved in angiogenesis include endothelial cell (EC) proliferation, sprouting, migration, tube formation, vessel remodeling, and pruning. In healthy tissues, angiogenesis is regulated by natural signals that prevent or stimulate the overgrowth of neovascularization [1].
Angiogenesis is a complex and multifactorial process that includes, but is not limited to, (i) stimulation by pro-angiogenic factors such as vascular endothelial growth factor (VEGF), basic fibroblast growth factor (bFGF), and transforming growth factor-beta (TGF- $\beta$ ); (ii) repression by anti-angiogenic factors (angiostatin, endostatin, and vasoinhibin); and (iii) regulation by non-angiogenic factors $\left(\mathrm{O}_{2}\right.$ consumption rate and nutrient deprivation threshold for early necrosis) [2-4]. Fibroblast growth factors (FGF) and VEGF-induced 
signal transduction led to specific biological responses. Both, (FGFs) and VEGFs, stimulate endothelial cells to secrete several proteases such as vascular endothelial growth factor receptor 2 (VEGFR2) and fibroblast growth factor receptor 1 (FGFR1). Thereby, signaling mediated by angiogenic stimulators, modulate the vasohibin (VASH) protein family. VASH1 and 2 are peptides linked to opposing angiogenic regulation processes [5]. VASH1 is an anti-angiogenic factor. It increases tubulin levels and thereby suppresses endocytosis, whereas VASH2 is proangiogenic and exhibits tubulin carboxypeptidase activity related to microtubule functions and facilitates tubulin detyrosination. Small vasohibin-binding protein (SVBP) is a protein that regulates the abundance of VASH1 and 2. VASHs, but not SVBP alone, increase detyrosination of $\alpha$-tubulin, and purified vasohibins remove the $\mathrm{C}$-terminal tyrosine of $\alpha$-tubulin [6]. The activities of VASH1 and 2 activities are linked to their expression sites. VASH1 is mainly produced by ECs [7], and VASH2 is mainly derived from infiltrating mononuclear cells [8]. VASH2 has also been detected in tumor cells [9]. VASH1 levels are low in proliferating ECs at the sprouting front and high in non-proliferating ECs at the angiogenesis termination zone where VASH1 possibly interrupts angiogenesis. Conversely, high levels of VASH2 are found at the sprouting front and lower levels at the termination zone [9].

Dysregulation of angiogenesis contributes to the development of numerous diseases, including cancer $[2,3,5,10-14]$. Cancer is "angiogenesis-dependent" [15] because it depends on neovasculature to fulfill the metabolic demands of cancer cell proliferation. Tumor vasculature offers an excellent and potentially selective target for anticancer therapy. Thus, significant advances in cancer treatment have been achieved with the development of antiangiogenic agents [16].

The overarching realm of vascular targeting strategies include both angiogenesis inhibiting agents (AIAs) and vascular disrupting agents (VDAs), which are collectively described as vascular targeting agents (VTAs) [17-21].

AIAs prevent the formation of new BV without acting on the pre-formed BV, and this limits tumor growth by blood deprivation [22]. Administration of AIAs can result in tumor cell necrosis and secondary tumor cell death $[17-19,21]$. Bevacizumab (beva) is classified as an AIA [23]. Beva is an anti-VEGFR antibody. It is a recombinant humanized monoclonal immunoglobulin G1 (IgG1), that contains a human framework region and a murine complementarity-determining region. It targets the VEGF receptor signaling pathway and blocks angiogenesis through ligand binding and sequestration. Beva causes EC apoptosis by blocking VEGFR1 [24], thus impairing cell proliferation, migration, survival, and vascular permeability [23]. Beva has been approved for several cancer indications, including breast cancer [25]; first-line non-squamous non-small cell lung cancer [26]; recurrent glioblastoma [27]; metastatic renal cell carcinoma [28]; persistent, recurrent, or metastatic cervical cancer [29]; epithelial ovarian cancer [30]; fallopian tube cancer; and primary peritoneal cancer [31]. Beva is the secondline treatment for patients with metastatic colon cancer (CC) who have progressed on a first-line beva-containing regimen $[18,19]$. Unfortunately, beva, aflibercept, and ramucirumab, like many other drugs, such as unitinib and pazopanib, that are designed to act specifically on a target proteins or receptors [32], may bind to unintended proteins and can exhibit off-target activity and adverse effects [18, $19,21,25]$.

VDAs are an emerging class of anticancer agents. They damage and destroy the existing tumor vasculature. VDAs depolymerize tubulin to disrupt tumor vascularization [20]. One subset of VDA functions is inhibition of microtubular tubulin, which leads to morphological changes to the ECs lining the tumor vasculature and triggers a cascade of cell signaling events that result in BV damage. Flavonoids, such as flavone-8acetic acid (FAA) [33] and dimethylxanthenone-4-acetic acid (DMXAA) or vadimezan are VDAs [34]. Another flavonoid, kaempferol, protects against retinal damage by regulating VASH1 and destroys retinal neovasculature [35]. Thus, the literature suggests that flavonoids are also a group of VDAs [33, 34].

Flavonoids have been shown to have effects on ovarian [36], breast [37, 38], prostate [39], liver [40], and colorectal cancer [41, 42]. Flavonoids are characterized by a phenyl benzo(y)pyrone-derived structure with putative anticancer effects [43-48]. While clinical use of quercetin is limited by its poor bioavailability, quercetin-3-O- $\beta$ d-glucopyranoside (Q3G or isoquercetin) has a better pharmacokinetic profile than quercetin [43-51]. It has an antiproliferative effect in vitro on CC cells (SW480, DLD-1, and HCT116) no significant effect on non-tumor colon cells (IEC-18) [52]. Considering this antiproliferative effect of Q3G on CC [52, 53], the evidence from flavonols as promising angiogenic agents, and also its relationship with VASHs [35, 54], we evaluated the antitumoral effect of Q3G in vivo and its relationship with vascularization in a xenogeneic $\mathrm{CC}$ animal model.

\section{RESULTS}

\section{CC animal model features}

Three $( \pm 1,09)$ days after xeno-transplantation tumor had $100 \mathrm{~mm}^{3}$. Untreated animals had tumors that presented as deep, fixed, and vascularized masses at the graft site. After incision, white tissue was observed, slightly lobulated and with a "fish-meat" aspect, which suggested a carcinoma tumor. Under microscopy, all tumors consisted of poorly differentiated adenocarcinoma with fibrotic beams separating the "nest" of desmoplastic tumor cells 
with frequent mitotic figures, including atypical forms and signet ring cells. Medium-and large-sized tumor cell clusters, acidophilus and ample cytoplasm, delicate chromatin nuclei, and evident nucleoli were also found. The connective tissue showed BV structures (Figure 1A and $1 \mathrm{~B})$.

\section{Treatment with Q3G or beva}

Tumors were smaller and less vascularized in Q3Gand beva-treated mice than in untreated mice (Figure 2A). There were fewer BVs in the tumors of Q3G- and beva-treated animals than in untreated animals (Figure 2B). Treatment with Q3G lowered tumor BV content to a greater extent than beva treatment (Figure 2B). None suffer signals were found in animals under Q3G treatment. The weight from day 0 to euthanasia day mice was stable. Untreated mice showed weight from $19,58 \pm 0,75$ to 19,98 $\pm 1,20$, Q3G-treated mice from $20,0 \pm 0,04$ to $20,22 \pm 1,56$ and beva-treated mice from $19,01 \pm 2,10$ to $21,23 \pm 4,75$ $(p=0.88)$.

VASH1 expression was increased by Q3G treatment, and VASH2 expression was lower in Q3G- and bevatreated CC compared to untreated $\mathrm{CC}$, and was higher in Q3G-treated CC in comparison to beva treatment (Figure 2B). The paucity BVs in the Q3G- and beva-treated tumors corresponded with their smaller size (Figure 2C).

We found VASH1 or 2 expressions at distinct sites in $\mathrm{CC}$ (Figure 3A and 3B). VASH1 was found in the extracellular matrix close to BVs (Figure 3A) whereas VASH2 was found in the cytoplasm (Figure 3B).

In Q3G-treated tumors, VASH1 expression was higher (Figure 4C) than untreated (Figure 4A) and Beva treated (Figure 4B) tumors, and VASH2 expression was lower (Figure 4F) in comparison to untreated (Figure 4D) and Beva treated (Figure 4E) tumors. On merged micrographs, we found a lower expression of VASH1 in ECs proliferating at the sprouting front. In turn, high levels of VASH1 were detected in non-proliferating ECs in the angiogenesis termination zone. High levels of VASH2 were found at the sprouting front and lowered in the termination zone in the cytoplasm (Figure 4G-4I).

\section{DISCUSSION}

Q3G and beva inhibited CC growth compared to untreated controls.Q3G showed $\mathrm{CC}$ inhibition in agreement with the known effects of flavonoids on several types of tumors and the antiproliferative effect of Q3G on CC cells in vitro [36-42, 55].

Q3G was safe to use. The clinical signs were used for the animal welfare refinement during animal experiments. The mice treated with Q3G showed no suffer signs. A 5\% body weight loss is a strong empirical predictor of pathological findings as a non-invasive tool to monitor research animal welfare in toxicity testing [56]. Data showed stability of weight in mice treated with Q3G.

In addition to smaller tumor size, Q3G treatment lowered the amount of BVs within tumors, whereas larger untreated tumors had more BVs. CC treated with Q3G showed approximately 65\% fewer BVs than untreated controls and 50\% fewer BV than tumors treated with beva. The results confirm that cancer is an "angiogenesis-dependent" variable [15]. The growing tumors need an increase in blood supply to obtain sufficient oxygen and nutrients. One way to obtain this is by stimulating angiogenesis. As a result of tumor expansion, the production of angiogenic occurs. It led to an increase in the intravascular distance and placed tumor cells beyond the critical oxygen diffusion limits. During the initial phase of angiogenesis, the existing

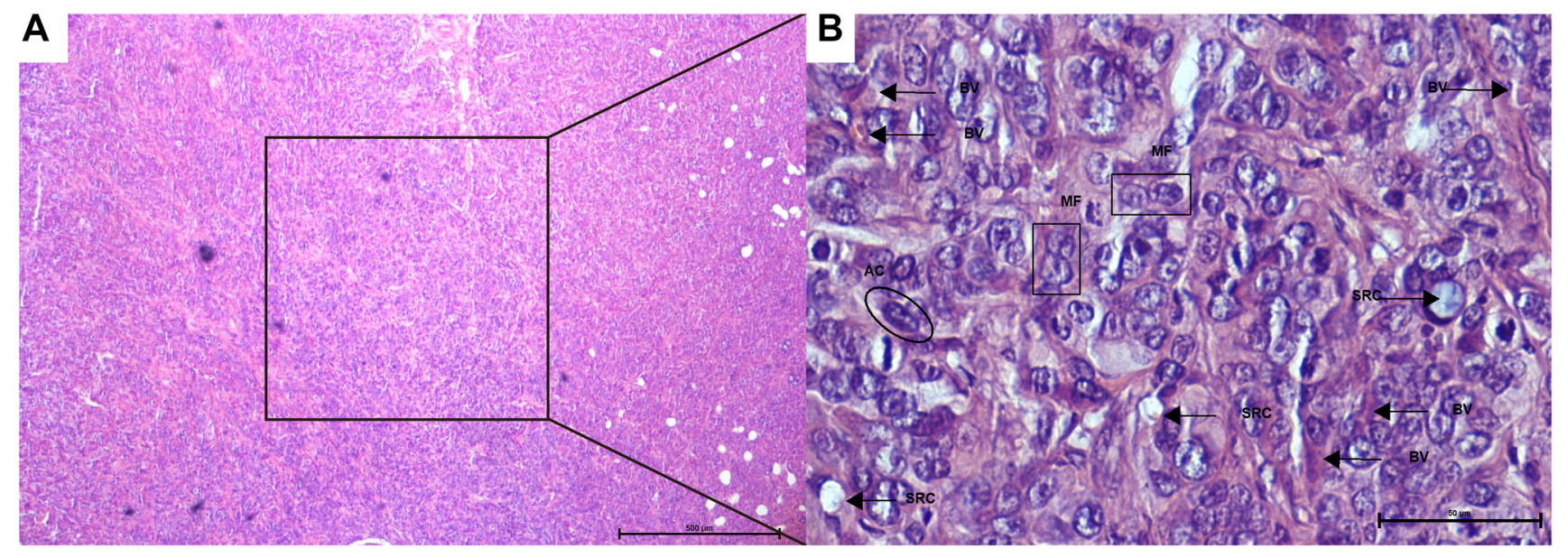

Figure 1: Photomicrographs of colon cancer histopathological features (A, B) following xenogeneic HT-29/CC cells seeding. (A) Global vision. Note the low differentiated adenocarcinoma (less than $25 \%$ of glandular formation). (B) Amplification of the square from image A. Note the mitotic figures (MF), including atypical and signet ring cells (SRC), fibrotic beams separating the "nests" of tumor cells, pleomorphic cells with acidophilic cytoplasm (AC), and the vessel structure in the connective tissue (BV). [HE A, 40×; HE B, 400×]. 
little BV become dilated, have increased permeability, and their endothelial cells show an increase in cytoplasmic organelles and a decrease of endothelial junctions. Subsequently, endothelial cells need to detach from and subsequently break down the basement membrane. They start migrating and proliferating to form new sprouts that enter growing tumor nests. Migrating endothelial cells align in loose cords and sprouts, and lumen formation occurs in the advancing sprout by vacuole formation and curving of the endothelial skeleton. When these sprouts become connected, blood flow will start [57]. These connected sprouts allow the

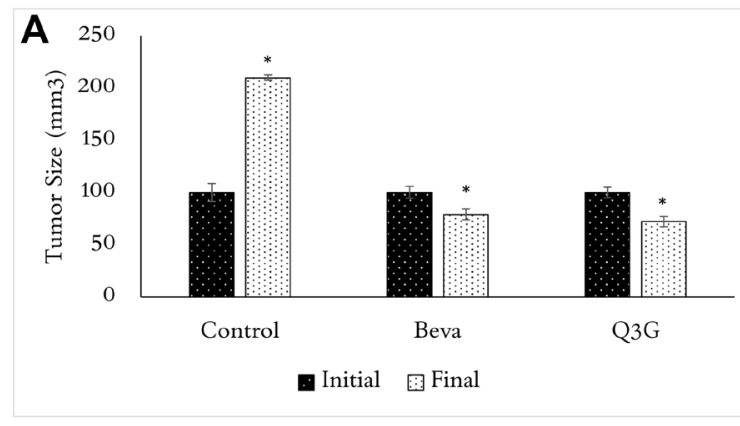

C

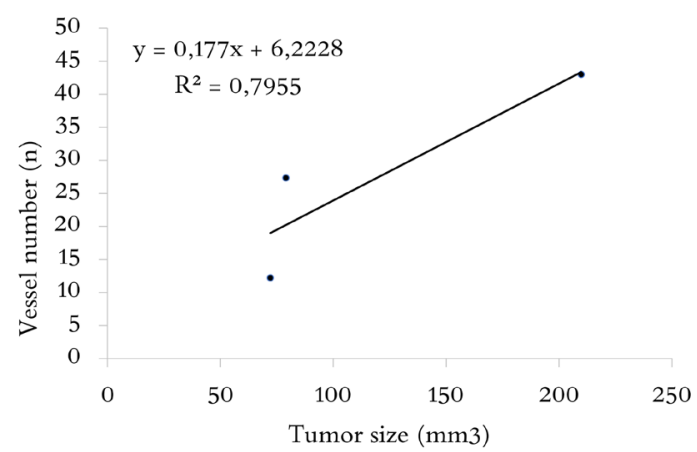

B

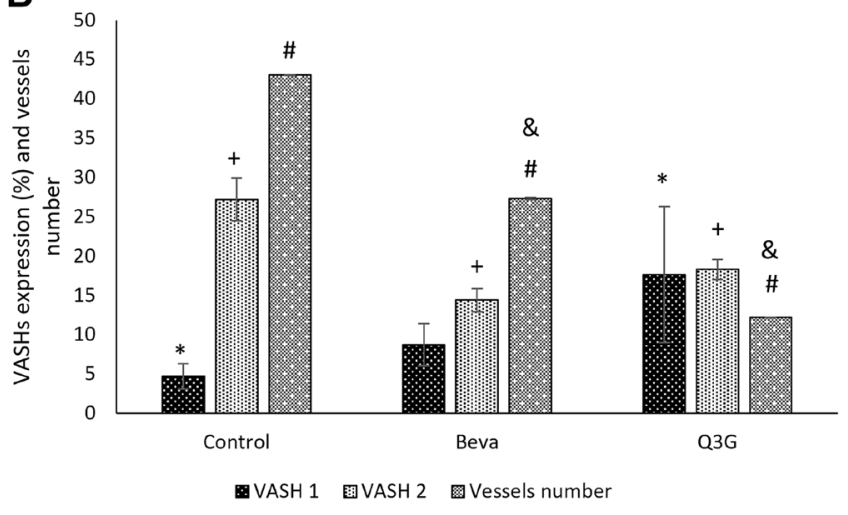

Figure 2: (A) Tumor size (mean \pm SD) in untreated mice and beva- or Q3G-treated groups following inoculation of xenogeneic HT-29 tumor cells at the day of treatment (initial) and after 7 days (final). At the initial time (day 0), the tumor size is the same in untreated or Q3Gor beva-treated mice, whereas, after 7 days of Q3G- or beva-treatment, the tumors are smaller in both beva and Q3G groups compared to the untreated group. ( $n=15$, non-parametric ANOVA (Kruscal Wallis), ${ }^{*} p<.05$ ). (B) VASH1 and 2 CC expression and blood vessel content in untreated (control) and beva- or Q3G- treated groups. Expression of VASH1 is higher in Q3G-treated tumors compared to untreated mice. VASH2 is lower in Q3G-treated tumors compared to untreated and higher compared to beva-treated mice. Blood vessels amount is lower in Q3G-treated tumors compared to untreated and beva-treated mice. ( $n=15$, non-parametric ANOVA (Kruscal Wallis), $\left.{ }^{*} p<.05\right)$. ( ${ }^{*}$ compared to VASH1, ${ }^{+}$compared toVASH2, ${ }^{\#, \&}$ compared to blood vessel number. $\left.{ }^{*},+,+, \&=p<.05\right)$. (C) Relationship between tumor size and blood vessel content. Note the tumor size as an "angiogenesis-dependent" variable $\left(n=15\right.$, Spearman test, $\mathrm{R}^{2}=$ adhesion to curve, rs $=$ $0,79, p<.05)$.

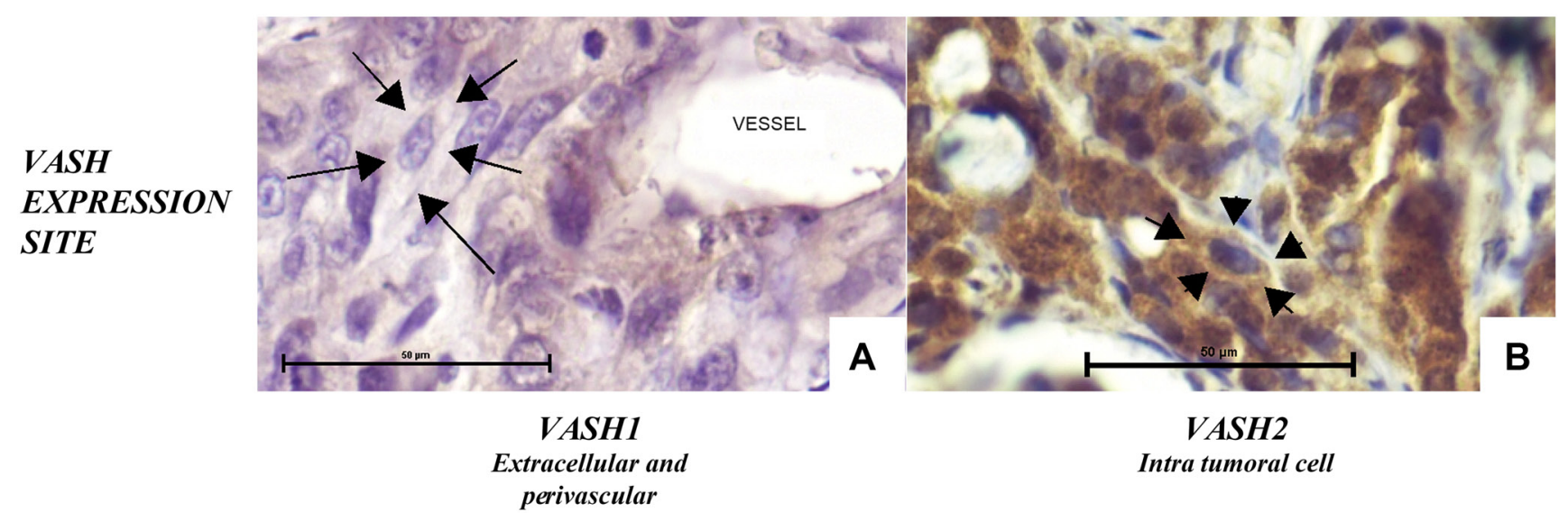

Figure 3: VASH1 (A) and VASH2 (B) expression in untreated CC. VASH1 was found in the extracellular matrix and endothelial cells, whereas VASH2 was found in the intracellular space. [Anti-VASH1 and anti-VASH2, 400×]. 
invaded tumor nests to grow and will themselves develop blood vessels and new sprouts leading to expansion of the tumor BV and tumor growth [58]. Therefore, cancer (growth, progression, and spread) is an angiogenesisdependent variable. Unprecedentedly, Q3G interfered with the vascularization of CC. In addition, Q3G-treated animals had higher VASH1 and lower VASH2 levels compared to untreated animals. The literature shows that inhibition of tumor growth occurs in response to impairment of angiogenesis by rutin [59, 60]. Rutin is a flavonoid from the same class of Q3G, which corroborates its antiangiogenic activity. Furthermore the literature reported that kaempferol interferes with VASH1 expression [36] and that engeletin regulates
VASH2 [54], which is consistent with the regulation of both angiogenic factors by flavonoids.

VASH1 and 2 have opposing activities that are linked to their expression sites. Antiangiogenic agents inhibit VASH production by blocking and sequestering VEGFR, which leads to EC apoptosis and vessel number reduction [61]. However, VASH1 expression is induced by numerous stimuli [62], including VASH2, and not exclusively by VEGFR.

Untreated tumors showed VASH1 mainly close to vascular structures in the extracellular matrix, whereas VASH2 was found within tumor cells. VASH1 impairs EC proliferation, migration, survival, and vascular permeability, which leads to angiogenic remodeling by

\section{CONTROL BEVA Q3G}

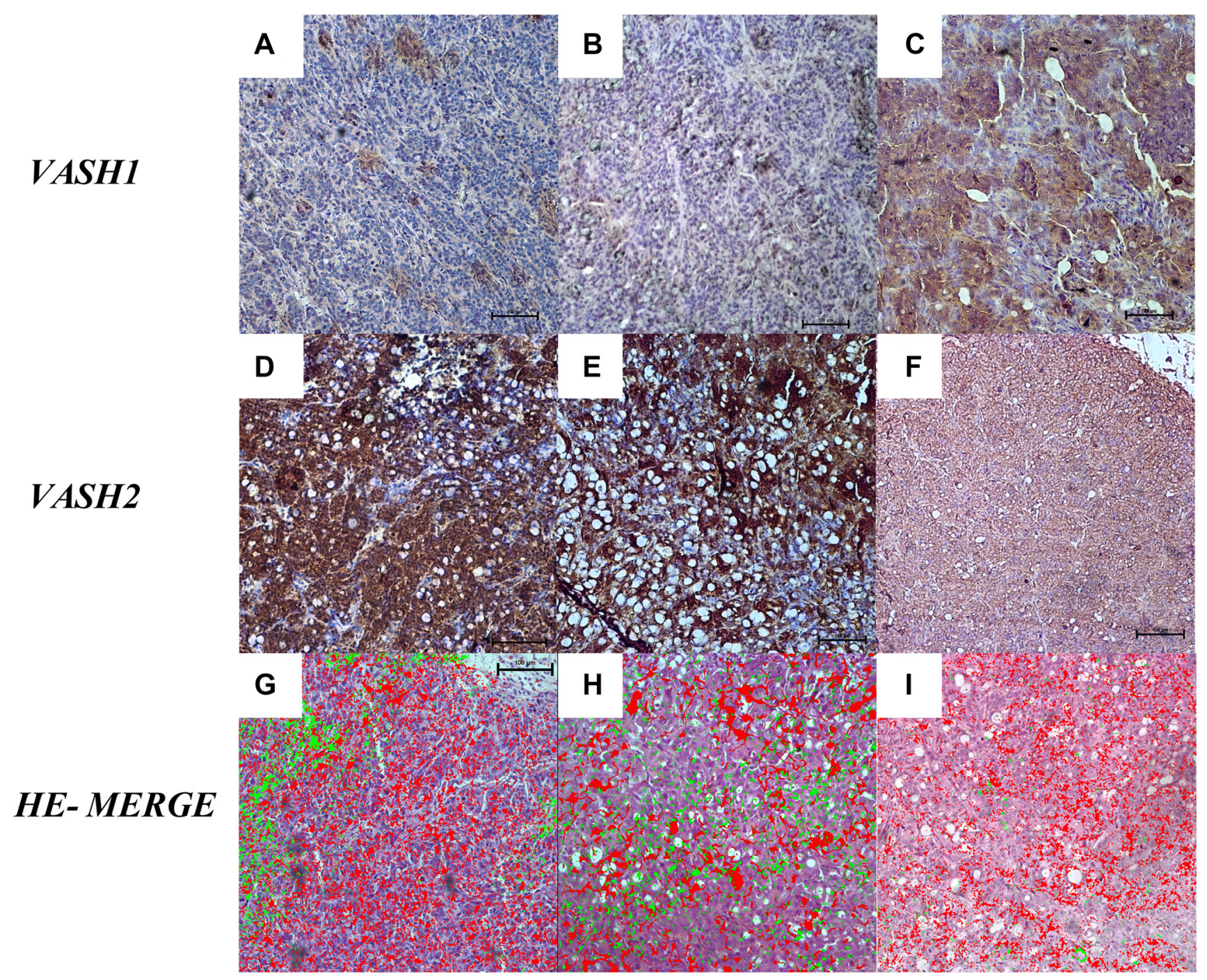

Figure 4: Tissue expression of VASHs $(\mathbf{A}-\mathbf{F})$ and VASHs-HE merged $(\mathbf{G}-\mathbf{I})$ in untreated $(\mathrm{A}, \mathrm{D}, \mathrm{G})$, beva-treated $(\mathrm{B}, \mathrm{E}, \mathrm{H})$, or Q3Gtreated $\mathrm{CC}(\mathrm{C}, \mathrm{F}, \mathrm{I})$. VASH1 shows higher expression $(\mathrm{C})$ and VASH2 lower expression $(\mathrm{F})$ in Q3G-treated CC compared to the control [Anti-VASH1 and anti-VASH2, 100x]. HE-Merged (G, H, I) images show VASH1 (red- in the front proliferation zone) and VASH2 (green- in the termination zone) tissue expression in distinct sites in CC. VASH1 was detected in the perivascular matrix, and VASH-2 was intracellular. [HE, 40×]. 
inhibiting angiogenic sprouting and vessel growth [63]. In untreated animals, we found low tissue expression of VASH1 and high VASH2. Q3G-treated animals showed higher tissue VASH1 expression localized in the extracellular matrix close to the EC proliferating zone in comparison to the control. In turn, VASH2 was found in the cytoplasm of tumor cells and was downregulated in comparison to cancer cells from control mice. The VASH1 was detected in the extracellular matrix (ECM) and EC but not in tumor cells. The spatial in ECM is crucial to ensure the proper assembly and maturation of new vascular structures by angiogenic signals. Consequently, the presence of VASH in ECM was expected. Distinct from VASH1, VASH2 was also found in the tumor cells. It is an exciting characteristic and suggests VASH2 as an inhibitor of angiogenic development mediated by the tumor cell. There are therapeutic challenges for delivering antiangiogenic, including controlling the microenvironmental distribution of their levels in tissue [64]. The VASH2 as a potential therapeutic strategy is less dependent on the ECM and molecular structure. It considers the target of the tumor cells, pointing to a therapeutic strategy not based on VASH1 and 2 molecular structures, but on their different expression sites. Although the evidence that human colon adenocarcinoma is angiogenesis-dependent, angiogenesis is not the only factor determining tumor growth, including genetic changes and biochemical pathways that play a crucial role. Tumor treatment with agents direct to only one target involved in tumor development and progression and spreading seems insufficient to induce complete tumor regression response and subsequent improvement of the disease-free and overall survival. Currently, distinct therapies should be maintained to interfere with different hallmarks of carcinogenesis, but the association with Q3G seems to be promising.

The distinct secondary pharmacology of the agents must be considered to understand Q3G activity. Angiogenic agents are segregated based on VDA or AIA effects and are organized based on their chemical structures. Many drugs, even those designed to act specifically on a target protein, bind unintended proteins and can exhibit off-target activity and thereby display dual mechanisms of action or pleiotropism. Most VDAs bind to tubulin or destabilize tubulin polymerization. Flavonoids such as FAA [33] and vadimezan [34] interfere with tubulin; thus, they are grouped as VDAs. We speculate that Q3G is a VDA mainly because of its interference with VASH expression, similar to kaempferol [36] which regulates VASH1 and Engeletin [54] that acts on VASH2.

VASH1 and 2 control tubulin detyrosination and thereby control the detyrosination status of polymerized microtubules. Tubulin detyrosination is implicated in many cell functions, such as cell division, and interferes with angiogenesis in vivo [65]. VASH1 increases tubulin levels, and VASH2 exerts its activity in microtubules. The tubulin carboxypeptidase activity of VASH1 inhibits angiogenesis by interfering with endocytosis and trafficking of receptors for pro-angiogenic factor. Recently, VASH1 was found to mediate tubulin detyrosination, a post-translational modification that allows the discrimination of mitotic errors that need to be corrected to prevent chromosomal instability, and is implicated in tumor evolution and metastasis [66, 67]. Additionally, VASH2 has microtubule functions and exhibits proangiogenic activity [67]. Considering the regulation of VASH1 and 2 and tubulin by Q3G, we suggest that Q3G has antiangiogenic activity in CC. Although the experimental design of this study proves that Q3G changes VASH1 and 2 expressions, and the number of vessels is correlated to VASHs expressions, the direct effect of VASHs expression under blood vessels deserves investigations after some VASH inhibition, like silencing or maybe using antibodies against VASHs.

Previous research has recognized the importance of the local tumor microenvironment in tumor progression and its role during carcinogenesis [14, 68]. VASH2 is expressed in CC cells and accelerates tumor angiogenesis and progression. Nevertheless, it is not expressed in most normal adult tissues [8], which suggests that it would offer more tumor-specific favorable outcomes for CC. VASH2 inhibition may be a useful therapeutic strategy for CC. The greater specificity of VASH2 than 1 in tumor cells suggests that VASH2 is a suitable target for blocking angiogenesis in $\mathrm{CC}$.

In summary, we determined the antitumor activity of Q3G in a xenogeneic CC mouse model. Unprecedentedly, Q3G interfered with the amount of BVs within tumors and regulated tissue VASH1 and 2 expression in CC. Although the experimental design of this study proves that Q3G changes VASH1 and 2 expressions, and the number of vessels is correlated to VASHs expressions, the direct effect of VASHs expression under blood vessels deserves investigations after some kind of VASH inhibition, like silencing or maybe using antibodies against VASHs.

\section{MATERIALS AND METHODS}

This study followed the principles outlined in the US Public Health Service Policy on Humane Care and Use of Laboratory Animals, and Guidelines for the Welfare of Animals in Experimental Neoplasia in strict accordance with the guidelines of the National Council of Animal Experimentation Control (CONCEA) and ARRIVE [69]. The Research Ethics Committee approved the protocol of Sao Francisco University (USF) under permit number 001.05.12.

The study involved 15 male Balb-c nude mice (6-8 weeks old, $20 \mathrm{~g}$ of weight) from Charles River Laboratory (Wilmington, DE, USA). The study was conducted at USF. Animals received water and standard chow ad libitum, except for 30 min before the Q3G treatment. The mice were maintained in a ventilated light-controlled 
rack animal housing system with controlled humidity and temperature and were exposed to $12 \mathrm{~h}$ light-dark cycles. We used environmental enrichment techniques and animal welfare inspection guide [70] to minimize stress and suffering in animals. Clinical signs such as piloerection, eyes half shut, slightly decreased motor activity and body weight loss were used to monitoring the animal welfare.

\section{Xenogeneic CC animal model}

Human CC/HT-29 cells (BCRJ code: 0111) were characterized by their DNA Profile (Amelogenin: X; CSF1PO: 11,12; D13S317: 11,12; D16S539: 11,12; D5S818: 11,12; D7S820: 10; THO1: 6,9; TPOX: 8,9; vWA: 17,19). These cells express urokinase receptors but do not have detectable plasminogen activator activity. HT-29 cells were negative for CD4, but there was cell-surface expression of galactose ceramide. These cells were obtained directly from Banco de Células do Rio de Janeiro (BCRJ, Brazil). Cells were thawed and propagated in culture following the International Guidelines on Good Cell Culture Practice [71]. Briefly, the cells were cultured at $37^{\circ} \mathrm{C}$ in a humidified chamber with $5 \% \mathrm{CO}_{2}$ using Dulbecco's modified Eagle medium (Sigma Aldrich, Brazil) supplemented with $100 \mathrm{mM}$ sodium pyruvate (Gibco), 10\% fetal bovine serum (Gibco, Thermo Fisher Scientific, Brazil), and 1\% antibiotic (penicillin and streptomycin, Gibco, Thermo Fisher Scientific, Brazil). HT-29 cells were detached from the culture plate following incubation with $3 \mathrm{~mL}$ Trypsin-EDTA $0.25 \%$ (Gibco, Thermo Fisher Scientific, Brazil) for $3 \mathrm{~min}$ for transfer or harvest. The culture medium was changed every $24 \mathrm{~h}$. Cell viability was evaluated using trypan blue staining. HT-29 cells (4 $\times 10^{6}$ ) were suspended in $40 \mu \mathrm{L}$ of normal saline and directly seeded into the subcutaneous tissue of the back left flank of athymic mice through a percutaneous puncture (27-gauge hypodermic needle) using a $1 \mathrm{~mL}$ syringe $[68,72,73]$.

After xeno-transplantation, tumor growth was checked daily using metal calipers. The formula "Volume $=\mathrm{L} \times \mathrm{S} \times \mathrm{S} / 2$ ", where " $\mathrm{S}$ " is the minor diameter measured and " $\mathrm{L}$ " is the largest diameter measured, was used to determine the CC volume [68, 72, 74].

\section{Groups}

The animals were randomly by lottery and distributed into three groups: untreated (negative control, $n=4$ ), Q3G-treated (test, $n=6$ ), or beva-treated (positive control, $n=5$ ).

Treatment was initiated when tumor volumes reached $100 \mathrm{~mm}^{3}$. Untreated animals received 0,5 $\mathrm{ml}$ of vehicle (saline, $0.9 \%$ sodium chloride solution) treatment; Q3G-treated animals received $0,5 \mathrm{ml}$ of
Q3G (Quercetin-3-Beta-D-Glucoside, \#17777793; Sigma Aldrich Brasil $^{\circledR}$ ) by gavage at the maximum non-lethal dose $(0.017 \mathrm{mg} / \mathrm{g}$ body weight $)$ over a week. The lethal dose of Q3G was determined as previously described by Chinedu et al., 2013 [75]. Beva-treated animals received beva (Roche, Brazil $\left.{ }^{\circledR}\right)(25 \mathrm{mg} / \mathrm{mL})$ by intraperitoneal injection $(0,5 \mathrm{~mL})$ at a single dose of 5 $\mathrm{mg} / \mathrm{kg}$ body weight, based on currently recommended dosage for initial therapy in metastatic colorectal cancer [76]. Seven days after the treatment (Q3G or beva), all animals were euthanized by administration of parenteral anesthetic drugs.

\section{Histological analyses}

The excised CC tissue was fixed in $10 \%$ formaldehyde solution, embedded in a paraffin block, and longitudinally sectioned. The slides of all tumors were named without group identification. Every slide was analyzed in three fields by three researchers. The data assumed the average among them. The slides $(4 \mu \mathrm{m})$ were stained with hematoxylin and eosin (HE). The presence of $\mathrm{CC}$, degree of differentiation, and microvascular quantification were determined. All identified vascular structures throughout the tumor surface were counted according to the International Consensus of Evaluation of Angiogenesis Quantification in Solid Human Tumors $[77,78]$. Microvascular quantification was performed using computerized image processing software (NIS for Windows) [79, 80].

\section{Immunohistochemical analysis}

Immunohistochemistry was performed using the avidin-biotin-peroxidase technique with an antiVASH1 antibody (HPA000653-100UL, Lot A06367; Sigma-Aldrich Corporation $^{\circledR}$, Saint Louis, MO, USA) or anti-VASH2 antibody (ab224723, Lot GR319965529) diluted at a 1:100 ratio in phosphate-buffered saline with 1\% bovine serum albumin (Sigma-Aldrich). Positive and negative immunohistochemistry controls were used to ensure the quality of the measurements. Immunoexpression microphotography and HE merged images were prepared to verify VASH1 and 2 tissue sites. A specific image analysis program (NIS for Windows) that combines the numerical values of the points in the color histogram that made up the image allows the user to determine the immunostaining by a numerical value in each field analyzed. To quantify VASH1 and 2 proteins a camera attached to the optical microscope captured the selected images in each slide. After capture, the images were evaluated by NIS Program. The measurement was made in a three field representative of the sample $[79,80]$. The average obtained after reading separate fields on the same slide was considered as the VASHs expressions $(\%)$. 


\section{Statistical analysis}

We performed a pilot study using nine animals (three for each group) to establish power and used a significance level of 0.90 that determined a minimum sample size of 12 animals (at least four for each group). The Statistical Package for the Social Sciences (SPSS) version 21.0 for Windows (IBM Corp., Armonk, NY, USA) was used for data analysis following descriptive statistics; measures of central tendency; normality test; non-parametric ANOVA (Kruskal Wallis) to compare size, BV content, VASH1 and 2 tissue expression; and Spearman correlation associated with the tumor size and BV content. Data were expressed as average and standard deviation, and a $\mathrm{p}$ less than 5\% $(p<.05)$ was used to reject the null hypothesis.

\section{Data availability}

Materials, data, and protocols should be made available upon request and within a reasonable amount of time from the corresponding author (depriolli@gmail. com) upon request.

\section{Abbreviations}

BV: Blood vessels; EC: Endothelial cell; VEGF: Vascular endothelial growth factor; bFGF: basic fibroblast growth factor; TGF- $\beta$ : Transforming growth factor-beta; FGF: Fibroblast growth factor; VEGFR2: Vascular endothelial growth factor receptor 2; FGFR1: Fibroblast growth factor receptor 1; VASH: Vasohibin; SVBP: Small vasohibin-binding protein; AIAs: Angiogenesis inhibiting agents; VDAs: Vascular disrupting agents; VTAs: Vascular targeting agents; beva: bevacizumab; CC: Colon cancer; IgG1: Immunoglobulin1; FAA: Flavone-8acetic acid; DMXAA: Dimethylxanthenone-4-acetic acid; Q3G: Quercetin-3-O- $\beta$-d-glucopyranoside; CONCEA: National Council of Animal Experimentation Control; HE: Hematoxylin and eosin; SPSS: Statistical Package for the Social Sciences.

\section{Author contributions}

DCS, GCO, and DGP devised the project, the main conceptual ideas, and the proof outline. GCO, IROA, IMM, AYK, JKYP, and JAP worked out almost all of the technical details and experiments. DGP performed the numerical calculations. DCS, JKYP, MGS, NPM, and SF wrote the draft manuscript. DGP supervised the project. All authors contributed to the final manuscript.

\section{CONFLICTS OF INTEREST}

Authors have no conflicts of interest to declare.

\section{FUNDING}

São Paulo Research Foundation - FAPESP \#2018/21471-5 (DGP); FAPESP (scholarship)\#2018/21906-1 (MGS); (scholarship)\#2017/25229-1 (IMM) and National Council for Scientific and Technological Development (CNPq) scholarship\#138932/2015-8 (GCO).

\section{REFERENCES}

1. Nowak-Sliwinska P, Alitalo K, Allen E, Anisimov A, Aplin AC, Auerbach R, Augustin HG, Bates DO, van Beijnum JR, Bender RHF, Bergers G, Bikfalvi A, Bischoff J, et al. Consensus guidelines for the use and interpretation of angiogenesis assays. Angiogenesis. 2018; 21:425-532. https://doi.org/10.1007/s10456-018-9613-x. [PubMed]

2. Mihalache A, Rogoveanu I. Angiogenesis factors involved in the pathogenesis of colorectal cancer. Curr Health Sci J. 2014; 40:5-11. https://doi.org/10.12865/CHSJ.40.01.01. [PubMed]

3. Mousa L, Salem ME, Mikhail S. Biomarkers of Angiogenesis in Colorectal Cancer. Biomark Cancer. 2015 (Suppl 1); 7:1319. https://doi.org/10.4137/BIC.S25250. [PubMed]

4. Clapp C, Thebault S, Martínez de la Escalera G. Hormones and postpartum cardiomyopathy. Trends Endocrinol Metab. 2007; 18:329-30. https://doi.org/10.1016/j. tem.2007.08.004. [PubMed]

5. Clapp C, Thebault S, Arnold E, García C, Rivera JC, de la Escalera GM. Vasoinhibins: novel inhibitors of ocular angiogenesis. Am J Physiol Endocrinol Metab. 2008; 295:E772-78. https://doi.org/10.1152/ajpendo.90358.2008. [PubMed]

6. Nieuwenhuis J, Adamopoulos A, Bleijerveld OB, Mazouzi A, Stickel E, Celie P, Altelaar M, Knipscheer P, Perrakis A, Blomen VA, Brummelkamp TR. Vasohibins encode tubulin detyrosinating activity. Science. 2017; 358:1453-56. https:// doi.org/10.1126/science.aao5676. [PubMed]

7. Kimura H, Miyashita H, Suzuki Y, Kobayashi M, Watanabe K, Sonoda H, Ohta H, Fujiwara T, Shimosegawa T, Sato Y. Distinctive localization and opposed roles of vasohibin-1 and vasohibin-2 in the regulation of angiogenesis. Blood. 2009; 113:4810-18. https://doi.org/10.1182/ blood-2008-07-170316. [PubMed]

8. Du H, Zhao J, Hai L, Wu J, Yi H, Shi Y. The roles of vasohibin and its family members: Beyond angiogenesis modulators. Cancer Biol Ther. 2017; 18:827-32. https:// doi.org/10.1080/15384047.2017.1373217. [PubMed]

9. Tan X, Liao Z, Zou S, Ma L, Wang A. VASH2 Promotes Cell Proliferation and Resistance to Doxorubicin in Non-Small Cell Lung Cancer via AKT Signaling. Oncol Res. 2020; 28:3-11. https://doi.org/10.3727/09650401 9X15509383469698. [PubMed] 
10. Sitohy B, Nagy JA, Dvorak HF. Anti-VEGF/VEGFR therapy for cancer: reassessing the target. Cancer Res. 2012; 72:1909-14. https://doi.org/10.1158/0008-5472.CAN-113406. [PubMed]

11. Yadav L, Puri N, Rastogi V, Satpute P, Sharma V. Tumour Angiogenesis and Angiogenic Inhibitors: A Review. J Clin Diagn Res. 2015; 9:XE01-05. https://doi.org/10.7860/ JCDR/2015/12016.6135. [PubMed]

12. González C, Parra A, Ramírez-Peredo J, García C, Rivera JC, Macotela Y, Aranda J, Lemini M, Arias J, Ibargüengoitia F, de la Escalera GM, Clapp C. Elevated vasoinhibins may contribute to endothelial cell dysfunction and low birth weight in preeclampsia. Lab Invest. 2007; 87:1009-17. https://doi.org/10.1038/labinvest.3700662. [PubMed]

13. Arnold E, Rivera JC, Thebault S, Moreno-Páramo D, Quiroz-Mercado H, Quintanar-Stéphano A, Binart N, Martínez de la Escalera G, Clapp C. High levels of serum prolactin protect against diabetic retinopathy by increasing ocular vasoinhibins. Diabetes. 2010; 59:3192-97. https:// doi.org/10.2337/db10-0873. [PubMed]

14. Jiang X, Wang J, Deng X, Xiong F, Zhang S, Gong Z, Li X, Cao K, Deng H, He Y, Liao Q, Xiang B, Zhou M, et al. The role of microenvironment in tumor angiogenesis. J Exp Clin Cancer Res. 2020; 39:204. https://doi.org/10.1186/s13046020-01709-5. [PubMed]

15. Ribatti D. Judah Folkman, a pioneer in the study of angiogenesis. Angiogenesis. 2008; 11:3-10. https://doi. org/10.1007/s10456-008-9092-6. [PubMed]

16. Leite C, Costa JVG, Callado RB, Torres JNL, Lima Júnior RCP, Ribeiro RA. Receptores tirosina-quinase: implicações terapêuticas no câncer. Revista Brasileira de Oncologia Clínica. 2012; 8:130-42. Available from https://www.sboc. org.br/app/webroot/Site_RBOC_OFICIAL/pdf_edicao_29/ artigo4.pdf.

17. Lippert JW 3rd. Vascular disrupting agents. Bioorg Med Chem. 2007; 15:605-15. https://doi.org/10.1016/j. bmc.2006.10.020. [PubMed]

18. Kataoka S, Nishikawa Y, Funakoshi T, Horimatsu T, Kondo $\mathrm{N}$, Matsubara T, Yanagita M, Matsumoto S, Muto M. Long-term survival and renal dysfunction in a patient with recurrent colorectal cancer treated with Bevacizumab. Clin J Gastroenterol. 2020; 13:316-19. https://doi.org/10.1007/ s12328-019-01060-z. [PubMed]

19. Fujii H, Matsuhashi N, Kitahora M, Takahashi T, Hirose C, Iihara H, Yamada Y, Watanabe D, Ishihara T, Suzuki A, Yoshida K. Bevacizumab in Combination with TAS-102 Improves Clinical Outcomes in Patients with Refractory Metastatic Colorectal Cancer: A Retrospective Study. Oncologist. 2020; 25:e469-76. https://doi.org/10.1634/ theoncologist.2019-0541. [PubMed]

20. Mason RP, Zhao D, Liu L, Trawick ML, Pinney KG. A perspective on vascular disrupting agents that interact with tubulin: preclinical tumor imaging and biological assessment. Integr Biol (Camb). 2011; 3:375-87. https:// doi.org/10.1039/c0ib00135j. [PubMed]

21. Shord SS, Bressler LR, Tierney LA, Cuellar S, George A. Understanding and managing the possible adverse effects associated with bevacizumab. Am J Health Syst Pharm. 2009; 66:999-1013. https://doi.org/10.2146/ajhp080455. [PubMed]

22. Mita MM, Sargsyan L, Mita AC, Spear M. Vasculardisrupting agents in oncology. Expert Opin Investig Drugs. 2013; 22:317-28. https://doi.org/10.1517/13543784.2013.7 59557. [PubMed]

23. Sebahar PR, Willardsen JA, Anderson MB. Anticancer Agents: VTA or VDA. Curr Bioact Compd. 2009; 5:79-97. https://doi.org/10.2174/157340709787580919.

24. Miyashita H, Watanabe T, Hayashi H, Suzuki Y, Nakamura T, Ito S, Ono M, Hoshikawa Y, Okada Y, Kondo T, Sato Y. Angiogenesis inhibitor vasohibin-1 enhances stress resistance of endothelial cells via induction of SOD2 and SIRT1. PLoS One. 2012; 7:e46459. https://doi.org/10.1371/ journal.pone.0046459. [PubMed]

25. Sasich LD, Sukkari SR. The US FDAs withdrawal of the breast cancer indication for Avastin (bevacizumab). Saudi Pharm J. 2012; 20:381-85. https://doi.org/10.1016/j. jisps.2011.12.001. [PubMed]

26. Sudo K, Sato K, Sakamoto S, Hasegawa Y, Asano M, Okuda Y, Takeda M, Sano M, Watanabe H, Shioya T, Ito H. Association Between Endothelial Progenitor Cells and Treatment Response in Non-Squamous Non-small Cell Lung Cancer Treated with Bevacizumab. Anticancer Res. 2017; 37:5565-71. https://doi.org/10.21873/ anticanres.11989. [PubMed]

27. Gleeson JP, Keane F, Keegan NM, Mammadov E, Harrold E, Alhusaini A, Harte J, Eakin-Love A, O'Halloran PJ, MacNally S, Hennessy BT, Breathnach OS, Grogan L, Morris PG. Similar overall survival with reduced vs. standard dose bevacizumab monotherapy in progressive glioblastoma. Cancer Med. 2020; 9:469-75. https://doi. org/10.1002/cam4.2616. [PubMed]

28. McDermott DF, Huseni MA, Atkins MB, Motzer RJ, Rini BI, Escudier B, Fong L, Joseph RW, Pal SK, Reeves JA, Sznol M, Hainsworth J, Rathmell WK, et al. Publisher Correction: Clinical activity and molecular correlates of response to atezolizumab alone or in combination with bevacizumab versus sunitinib in renal cell carcinoma. Nat Med. 2018; 24:1941. https://doi.org/10.1038/s41591-018$\underline{0235-\mathrm{z}}$. [ $\underline{\mathrm{PubMed}}]$

29. Minion LE, Tewari KS. The safety and efficacy of bevacizumab in the treatment of patients with recurrent or metastatic cervical cancer. Expert Rev Anticancer Ther. 2017; 17:191-98. https://doi.org/10.1080/14737140.2016.1 246187. [PubMed]

30. Haunschild CE, Tewari KS. Bevacizumab use in the frontline, maintenance and recurrent settings for ovarian cancer. Future Oncol. 2020; 16:225-46. https://doi. org/10.2217/fon-2019-0042. [ [PubMed] 
31. Shoji T, Komiyama S, Kigawa J, Tanabe H, Kato K, Itamochi H, Fujiwara H, Kamiura S, Hamano T, Sugiyama $\mathrm{T}$, and Japanese Gynecologic Oncology Group. An openlabel, randomized, phase II trial evaluating the efficacy and safety of standard of care with or without bevacizumab in platinum-resistant epithelial ovarian, fallopian tube, or primary peritoneal cancer patients previously treated with bevacizumab for front-line or platinum-sensitive ovarian cancer: rationale, design, and methods of the Japanese Gynecologic Oncology Group study JGOG3023. BMC Cancer. 2018; 18:771. https://doi.org/10.1186/s12885-0184505-4. [PubMed]

32. Di Lorenzo G, Porta C, Bellmunt J, Sternberg C, Kirkali Z, Staehler M, Joniau S, Montorsi F, Buonerba C. Toxicities of targeted therapy and their management in kidney cancer. Eur Urol. 2011; 59:526-40. https://doi.org/10.1016/j. eururo.2011.01.002. [PubMed]

33. Mahadevan V, Malik ST, Meager A, Fiers W, Lewis GP, Hart IR. Role of tumor necrosis factor in flavone acetic acid-induced tumor vasculature shutdown. Cancer Res. 1990; 50:5537-42. [PubMed]

34. Rustin GJ, Bradley C, Galbraith S, Stratford M, Loadman P, Waller S, Bellenger K, Gumbrell L, Folkes L, Halbert G, and Phase I/II Trials Committee of Cancer Research UK. 5,6-dimethylxanthenone-4-acetic acid (DMXAA), a novel antivascular agent: phase I clinical and pharmacokinetic study. Br J Cancer. 2003; 88:1160-67. https://doi. org/10.1038/sj.bjc.6600885. [PubMed]

35. Zhao L, Sun J, Shi S, Qin X, Zhang K, Xu J. Kaempferol protects retinal ganglion ceils from high-glucose-induced injury by regulating vasohibin-1. Neurosci Lett. 2020; 716:134633. https://doi.org/10.1016/j.neulet.2019.134633. [PubMed]

36. Luo H, Rankin GO, Liu L, Daddysman MK, Jiang BH, Chen YC. Kaempferol inhibits angiogenesis and VEGF expression through both HIF dependent and independent pathways in human ovarian cancer cells. Nutr Cancer. 2009; 61:554-63. https://doi.org/10.1080/01635580802666281. [PubMed]

37. Wen W, Lu J, Zhang K, Chen S. Grape seed extract inhibits angiogenesis via suppression of the vascular endothelial growth factor receptor signaling pathway. Cancer Prev Res (Phila). 2008; 1:554-61. https://doi.org/10.1158/1940-6207. CAPR-08-0040. [PubMed]

38. Namvar F, Mohamad R, Baharara J, Zafar-Balanejad S, Fargahi F, Rahman HS. Antioxidant, antiproliferative, and antiangiogenesis effects of polyphenol-rich seaweed (Sargassum muticum). Biomed Res Int. 2013; 2013:604787. https://doi.org/10.1155/2013/604787. [PubMed]

39. Adjakly M, Ngollo M, Boiteux JP, Bignon YJ, Guy L, Bernard-Gallon D. Genistein and daidzein: different molecular effects on prostate cancer. Anticancer Res. 2013; 33:39-44. [PubMed]

40. Lee JH, Lee DH, Lee HS, Choi JS, Kim KW, Hong SS. Deguelin inhibits human hepatocellular carcinoma by antiangiogenesis and apoptosis. Oncol Rep. 2008; 20:12934. [PubMed]

41. Chen Y, Wu Q, Song L, He T, Li Y, Li L, Su W, Liu L, Qian Z, Gong C. Polymeric micelles encapsulating fisetin improve the therapeutic effect in colon cancer. ACS Appl Mater Interfaces. 2015; 7:534-42. https://doi.org/10.1021/ am5066893. [PubMed]

42. Zhu XF, Xie BF, Zhou JM, Feng GK, Liu ZC, Wei XY, Zhang FX, Liu MF, Zeng YX. Blockade of vascular endothelial growth factor receptor signal pathway and antitumor activity of ON-III (2',4'-dihydroxy6'-methoxy-3',5'-dimethylchalcone), a component from Chinese herbal medicine. Mol Pharmacol. 2005; 67:1444-50. https://doi.org/10.1124/mol.104.009894. [PubMed]

43. Heim KE, Tagliaferro AR, Bobilya DJ. Flavonoid antioxidants: chemistry, metabolism and structure-activity relationships. J Nutr Biochem. 2002; 13:572-84. https://doi. org/10.1016/s0955-2863(02)00208-5. [PubMed]

44. Begum AN, Terao J. Protective effect of quercetin against cigarette tar extract-induced impairment of erythrocyte deformability. J Nutr Biochem. 2002; 13:265-72. https:// doi.org/10.1016/s0955-2863(01)00219-4. [PubMed]

45. Shimada Y, Dewa Y, Ichimura R, Suzuki T, Mizukami S, Hayashi SM, Shibutani M, Mitsumori K. Antioxidant enzymatically modified isoquercitrin suppresses the development of liver preneoplastic lesions in rats induced by beta-naphthoflavone. Toxicology. 2010; 268:213-18. https://doi.org/10.1016/j.tox.2009.12.019. [PubMed]

46. Jung $\mathrm{SH}, \mathrm{Kim} \mathrm{BJ}$, Lee $\mathrm{EH}$, Osborne NN. Isoquercitrin is the most effective antioxidant in the plant Thuja orientalis and able to counteract oxidative-induced damage to a transformed cell line (RGC-5 cells). Neurochem Int. 2010; 57:713-21. https://doi.org/10.1016/j.neuint.2010.08.005. [PubMed]

47. Amado NG, Fonseca BF, Cerqueira DM, Neto VM, Abreu JG. Flavonoids: potential Wnt/beta-catenin signaling modulators in cancer. Life Sci. 2011; 89:545-54. https:// doi.org/10.1016/j.1fs.2011.05.003. [PubMed]

48. Kim BH, Choi JS, Yi EH, Lee JK, Won C, Ye SK, Kim $\mathrm{MH}$. Relative antioxidant activities of quercetin and its structurally related substances and their effects on NF- $\kappa \mathrm{B} /$ CRE/AP-1 signaling in murine macrophages. Mol Cells. 2013; 35:410-20. https://doi.org/10.1007/s10059-0130031-z. [PubMed]

49. National Cancer Institute. Isoquercetin. Definitions. 2020. https://doi.org/10.32388/xr8450.

50. Appleton J. Evaluating the Bioavailability of Isoquercetin. Natural Medicine Journal. 2010; 2. Available from: http:// www.naturalmedicinejournal.com/journal/2010-01/ evaluating-bioavailability-isoquercetin.

51. Olthof MR, Hollman PC, Vree TB, Katan MB. Bioavailabilities of quercetin-3-glucoside and quercetin-4'- 
glucoside do not differ in humans. J Nutr. 2000; 130:1200 03. https://doi.org/10.1093/jn/130.5.1200. [PubMed]

52. Amado NG, Predes D, Fonseca BF, Cerqueira DM, Reis AH, Dudenhoeffer AC, Borges HL, Mendes FA, Abreu JG. Isoquercitrin suppresses colon cancer cell growth in vitro by targeting the $\mathrm{Wnt} / \beta$-catenin signaling pathway. J Biol Chem. 2014; 289:35456-67. https://doi.org/10.1074/jbc. M114.621599. [PubMed]

53. Salucci M, Stivala LA, Maiani G, Bugianesi R, Vannini V. Flavonoids uptake and their effect on cell cycle of human colon adenocarcinoma cells (Caco2). Br J Cancer. 2002; 86:1645-51. https://doi.org/10.1038/sj.bjc.6600295. [PubMed]

54. Liu H, Li S, Xu Y, Wang X, Ren R, Zhu H, Zhang S. Engeletin protects against cerebral ischemia/reperfusion injury by modulating the VEGF/vasohibin and Ang-1/Tie-2 pathways. Braz J Med Biol Res. 2021; 54:e11028. https:// doi.org/10.1590/1414-431X2020e11028. [PubMed]

55. Yang F, Jiang X, Song L, Wang H, Mei Z, Xu Z, Xing N. Quercetin inhibits angiogenesis through thrombospondin-1 upregulation to antagonize human prostate cancer PC-3 cell growth in vitro and in vivo. Oncol Rep. 2016; 35:1602-10. https://doi.org/10.3892/or.2015.4481. [PubMed]

56. Silva AV, Norinder U, Liiv E, Platzack B, Öberg M, Törnqvist E. Associations between clinical signs and pathological findings in toxicity testing. ALTEX. 2021; 38:198-214. https://doi.org/10.14573/altex.2003311. [PubMed]

57. Carmeliet P, Jain RK. Angiogenesis in cancer and other diseases. Nature. 2000; 407:249-57. https://doi. org/10.1038/35025220. [PubMed]

58. Schlingemann RO, Rietveld FJ, de Waal RM, Bradley NJ, Skene AI, Davies AJ, Greaves MF, Denekamp J, Ruiter DJ. Leukocyte antigen CD34 is expressed by a subset of cultured endothelial cells and on endothelial abluminal microprocesses in the tumor stroma. Lab Invest. 1990; 62:690-96. [ubMed]

59. Alonso-Castro AJ, Domínguez F, García-Carrancá A. Rutin exerts antitumor effects on nude mice bearing SW480 tumor. Arch Med Res. 2013; 44:346-51. https://doi. org/10.1016/j.arcmed.2013.06.002. [PubMed]

60. Del Follo-Martinez A, Banerjee N, Li X, Safe S, MertensTalcott S. Resveratrol and quercetin in combination have anticancer activity in colon cancer cells and repress oncogenic microRNA-27a. Nutr Cancer. 2013; 65:494-504. https://doi.org/10.1080/01635581.2012.725194. [PubMed]

61. Huang B, Huang M, Li Q. Cancer-Associated Fibroblasts Promote Angiogenesis of Hepatocellular Carcinoma by VEGF-Mediated EZH2/VASH1 Pathway. Technol Cancer Res Treat. 2019; 18:1533033819879905. https://doi. org/10.1177/1533033819879905. [PubMed]

62. Takahashi Y, Saga Y, Koyanagi T, Takei Y, Machida S, Taneichi A, Mizukami H, Sato Y, Matsubara S, Fujiwara H. Vasohibin-1 expression inhibits advancement of ovarian cancer producing various angiogenic factors. Cancer Sci. 2016; 107:629-37. https://doi.org/10.1111/cas.12911. [PubMed]

63. Kern J, Steurer M, Gastl G, Gunsilius E, Untergasser G. Vasohibin inhibits angiogenic sprouting in vitro and supports vascular maturation processes in vivo. BMC Cancer. 2009; 9:284. https://doi.org/10.1186/1471-2407-9284. [PubMed]

64. Martino MM, Brkic S, Bovo E, Burger M, Schaefer DJ, Wolff T, Gürke L, Briquez PS, Larsson HM, GianniBarrera R, Hubbell JA, Banfi A. Extracellular matrix and growth factor engineering for controlled angiogenesis in regenerative medicine. Front Bioeng Biotechnol. 2015; 3:45. https://doi.org/10.3389/fbioe.2015.00045. [PubMed]

65. de Oliveira MB, Meier K, Jung S, Bartels-Klein E, Coxam B, Geudens I, Szymborska A, Skoczylas R, Fechner I, Koltowska K, Gerhardt H. Vasohibin 1 selectively regulates secondary sprouting and lymphangiogenesis in the zebrafish trunk. Development. 2021; 148:dev194993. https://doi. org/10.1242/dev.194993. [PubMed]

66. Lopes D, Maiato H. The Tubulin Code in Mitosis and Cancer. Cells. 2020; 9:2356. https://doi.org/10.3390/ cells9112356. [ubMed]

67. Kobayashi M, Wakabayashi I, Suzuki Y, Fujiwara K, Nakayama M, Watabe T, Sato Y. Tubulin carboxypeptidase activity of vasohibin-1 inhibits angiogenesis by interfering with endocytosis and trafficking of pro-angiogenic factor receptors. Angiogenesis. 2021; 24:159-76. https://doi. org/10.1007/s10456-020-09754-6. [PubMed]

68. Priolli DG, Abrantes AM, Neves S, Gonçalves AC, Lopes CO, Martinez NP, Cardinalli IA, Ribeiro AB, Botelho MF. Microenvironment influence on human colon adenocarcinoma phenotypes and matrix metalloproteinase-2, p53 and $\beta$-catenin tumor expressions from identical monoclonal cell tumor in the orthotopic model in athymic nude rats. Scand J Gastroenterol. 2014; 49:309-16. https://doi.org/10.3109/00365521.2013.86935 0. [ PubMed]

69. The ARRIVE guidelines 2.0. Available $2021 \mathrm{Sep} 22$, from https://arriveguidelines.org/arrive-guidelines.

70. Bennett BT, Cardon AD, Bailey MR. Revisions to the animal welfare inspection guide. Lab Anim (NY). 2015; 44:201. https://doi.org/10.1038/laban.779. [PubMed]

71. Bal-Price A, Coecke S. Guidance on Good Cell Culture Practice (GCCP). Neuromethods. Totowa, NJ: Humana Press. 2011; 56:1-25. https://doi.org/10.1007/978-1-61779077-5 1.

72. Priolli DG, Abrantes AM, Neves S, Batista JN, Cardinalli IA, Botelho MF. A novel model of distal colon cancer in athymic mice. Acta Cir Bras. 2012; 27:355-60. https://doi. org/10.1590/s0102-86502012000600001. [PubMed]

73. Caetano-Oliveira R, Gomes MA, Abrantes AM, TavaresSilva E, Oliveira MC, Laranjo M, Queirós DB, CasaltaLopes J, Pires S, Carvalho L, Gouveia R, Santos PR, Priolli 
DG, et al. Revisiting colorectal cancer animal model - An improved metastatic model for distal rectosigmoid colon carcinoma. Pathophysiology. 2018; 25:89-99. https://doi. org/10.1016/j.pathophys.2018.02.002. [PubMed]

74. Tomayko MM, Reynolds CP. Determination of subcutaneous tumor size in athymic (nude) mice. Cancer Chemother Pharmacol. 1989; 24:148-54. https://doi. org/10.1007/BF00300234. [PubMed]

75. Chinedu E, Arome D, Ameh FS. A new method for determining acute toxicity in animal models. Toxicol Int. 2013; 20:224-26. https://doi.org/10.4103/09716580.121674. [PubMed]

76. Chase JL. Clinical use of anti-vascular endothelial growth factor monoclonal antibodies in metastatic colorectal cancer. Pharmacotherapy. 2008; 28:23S-30S. https://doi. org/10.1592/phco.28.11-supp.23S. [PubMed]

77. Weidner N, Semple JP, Welch WR, Folkman J. Tumor angiogenesis and metastasis--correlation in invasive breast carcinoma. N Engl J Med. 1991; 324:1-8. https://doi. org/10.1056/NEJM199101033240101. [PubMed]
78. Vermeulen PB, Gasparini G, Fox SB, Colpaert C, Marson LP, Gion M, Beliën JA, de Waal RM, Van Marck E, Magnani E, Weidner N, Harris AL, Dirix LY. Second international consensus on the methodology and criteria of evaluation of angiogenesis quantification in solid human tumours. Eur J Cancer. 2002; 38:1564-79. https://doi. org/10.1016/s0959-8049(02)00094-1. [PubMed]

79. Martinez NP, Kanno DT, Pereira JA, Cardinalli IA, Priolli DG. Beta-catenin and E-cadherin tissue "content" as prognostic markers in left-side colorectal cancer. Cancer Biomark. 2010-2011; 8:129-35. https://doi.org/10.3233/ DMA-2011-0843. [PubMed]

80. Priolli DG, Martinez CA, Piovesan H, Cardinalli IA, Margarido NF, Waisberg J. Morphofunctional malignancy grading is a valuable prognostic factor for colorectal cancer. Arq Gastroenterol. 2010; 47:225-32. https://doi. org/10.1590/s0004-28032010000300003. [PubMed] 